\title{
Article
}

\section{Solidarities and Tensions in Mental Health Politics: Mad Studies and Psychopolitics}

Cresswell, Mark and Spandler, Helen

Available at http://clok.uclan.ac.uk/15742/

Cresswell, Mark and Spandler, Helen ORCID: 0000-0002-0970-5141 (2016)

Solidarities and Tensions in Mental Health Politics: Mad Studies and

Psychopolitics. Critical and Radical Social Work . ISSN 20498608

It is advisable to refer to the publisher's version if you intend to cite from the work. http://dx.doi.org/10.1332/204986016×14739257401605

For more information about UCLan's research in this area go to http://www.uclan.ac.uk/researchgroups/ and search for <name of research Group>.

For information about Research generally at UCLan please go to http://www.uclan.ac.uk/research/

All outputs in CLoK are protected by Intellectual Property Rights law, including Copyright law. Copyright, IPR and Moral Rights for the works on this site are retained by the individual authors and/or other copyright owners. Terms and conditions for use of this material are defined in the policies page.

\section{CLoK}

Central Lancashire online Knowledge www.clok.uclan.ac.uk

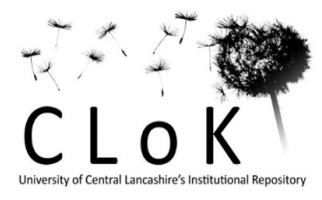




\title{
article
}

\section{Solidarities and tensions in mental health politics: Mad Studies and Psychopolitics}

\author{
Mark Cresswell, markcresswell@mail.com \\ University of Surrey, UK \\ Helen Spandler, hspandler@uclan.ac.uk \\ University of Central Lancashire, UK
}

\begin{abstract}
Recent years have seen a resurgence in radical mental health politics and accompanying social movements. This article identifies two tendencies. The first, the Mad Studies tendency, indicts psychiatry as a branch of medicine and asserts a politics of identity based upon the experience of 'madness'. The second, the Psychopolitics tendency, defends the value of welfare and medicine and asserts a politics of alliance between service users and mental health workers. Using three recent texts, Mad matters (2013), Psychiatry disrupted (2014) and Madness, distress and the politics of disablement (2015), this article analyses the solidarities and tensions that exist within and between these tendencies.
\end{abstract}

key words mental health $\cdot$ social movements $\cdot$ austerity $\cdot$ Mad Studies $\cdot$ politics of welfare

\section{Introduction}

Recent years have witnessed a resurgence in radical mental health politics. especially in the US, Canada and the UK. Three texts signal this resurgence: Mad matters: $A$ critical reader in Canadian Mad Studies (LeFrancois et al, 2013), edited by Brenda LeFrancois, Robert Menzies and Geoffrey Reaume; Psychiatry distupted: Theorizing resistance and crafting the (r)evolution (Burstow et al, 2014), edited by Bonnie Burstow, Brenda LeFrancois and Shaindl Diamond; and Madness, distress and the politics of disablement (Spandler et al, 2015), edited by Helen Spandler, Jill Anderson and Bob Sapey. They are significant for three reasons: first, their historical proximity signifies the intensification of a social movement; second, their anthological form signifies the scope of their coverage; and, third, their interconnected network of authorship signifies, if not a unity, then a continuity in the membership of that movement.

Without reducing political activism to its textual representations, these texts offer a useful resource to explore contemporary debates. In particular, this article uses them to analyse solidarities and tensions in modern mental health movements. Their geographical focus is confined to the English-speaking world: Mad matters is specifically Canadian; Psychiatry disrupted is North American; and Madness, distress and the politics of disablement is more UK-focused. 
Although a radical mental health politics has a long history, marked by both continuities and ruptures (see Survivors History Group, 2011), ${ }^{1}$ we identify a resurgence from 2008 onwards. This had two causes: first, the global financial crisis, which heralded a period of economic austerity and welfare cuts impacting upon mental health services; and, second, an intensification of concerns with 'madness' considered as an experience and an identity with its own distinctive features and intersected with specific oppressions. These triggers have re-energised mental health movements, providing new sources of solidarity while simultaneously uncovering underlying tensions.

These tensions can be witnessed in two tendencies within radical mental health politics: first, the Mad Studies tendency, which is influenced by anti-psychiatry, Mad Pride movements and other identity-based struggles, notably, black feminism (eg Hill Collins, 2000); and, second, the Psychopolitics tendency, which is influenced by European welfarism and revolutionary Marxism. ${ }^{2}$ This tradition often refers to Peter Sedgwick's (2015 [1982]) text, Psychopolitics - although we make a distinction here between Sedgwick's actual book and the post-Sedwickian political tendency that we call Psychopolitics. While neither Mad Studies nor Psychopolitics is entirely new, both are experiencing a resurgence in the current context. If the Mad Studies tendency was ignited by the 'Madness, Citizenship and Social Justice Conference' held in Canada in June 2008, and the publication of Mad matters in 2013, then the signifiers of the second tendency were the 'Psychopolitics in the 21st Century' conference held in England in June 2015 and the republication of Sedgwick's original work later that year (Sedgwick, 2015 [1982]).

Mad Studies and Psychopolitics are not mutually exclusive. Many, like ourselves, have identified with the Psychopolitics tendency but are sympathetic to Mad Studies - and vice versa. Nor are we claiming that an iron logic governs either tendency. That is why we call them 'tendencies'; they exhibit direction but are in a state of movement and change. While Mad Studies is built upon traditions of anti-psychiatry, its aspiration is to remain ideologically 'open' (Menzies et al, 2013:11). Indeed, in the introduction to Mad matters, Menzies et al (2013:11) refer to 'ongoing controversies, areas of contention, and competing understandings' within the Mad Studies project. At the same time, while Psychopolitics often refers to Sedgwick's work, contemporary manifestations often depart from his tenets. That is why contemporary Psychopolitics should be described as post-Sedgwickian. For instance, the debate in this journal between Tad Tietze and ourselves (Cresswell and Spandler, 2015; Tietze, 2015) disagreed about Sedgwick's legacy for the politics of mental health from within that tendency.

While the Mad Studies-Psychopolitics distinction is not mutually exclusive, it is also more than a heuristic. It demarcates differences that have implications for political strategy. A key purpose of this article is to maintain a balance between the tensions and solidarities existing within and between these tendencies. If, at times, we stress the tensions as much as the solidarities, it is because we are consciously resisting the temptation to 'sweep things under the carpet'. Often, for good reasons, activists stress solidarities rather than tensions, perhaps because the tensions feel too 'personal', perhaps in the hope that they may disappear (McKeown and Spandler, 2015). Our view is that they rarely disappear, and insofar as they represent real differences, they are best spoken about. Expressed another way, this article is both analytic and normative: analytic in the sense that it identifies sources of solidarity and tension within mental 
health politics; normative in the sense that it argues for a recognition of both as a precondition of political action.

We structure our analysis around three key axes of tension and solidarity ${ }^{3}$ :

1. Mad experience.

2. Service provision.

3. Critical pedagogy.

The next three sections analyse the solidarities and tensions arising within Mad Studies and Psychopolitics in terms of each axis. We then provide a summary of tensions and solidarities existing within and between each tendency.

\section{Mad experience}

\section{Mad experience and Mad Studies}

Mad Studies attempts to redefine the experience of 'mental illness' and reclaim madness as a political identity. The use of the term 'Mad' (upper case) instead of 'mad' (lower case) signifies the politicisation of madness as an oppressed identity. In Mad matters, madness is referred to as a 'historical, rather than a descriptive or essential category, proposed for political action and discussion' (Menzies et al, 2013: 11). This is a similar strategy to Queer Studies (eg Butler, 1990), which engages in intellectual critique and political action but without essentialising queer experience. While such social constructionism is potentially radical, it does beg the question of what constitutes the 'madness' - the original experience - which we then use as a basis for political action.

In Mad matters, Mad Studies' definition of madness has a revealing two-part structure consisting of an assertion of identity followed by an indictment of psychiatric oppression. For example, 'Mad Studies takes as its principal ... raison d'etre the subjectivities, embodiments, words, experiences, and aspirations of those among us whose lives have collided with the powers of ... psychiatry' (Menzies et al, 2013: 13-14). This indictment includes, not just biomedical psychiatry, but any profession linked to psychiatry (such as psychology, nursing, social work, etc). This echoes a critique of the ever-expanding 'reach' of psychiatric power and includes what are often called the 'psy disciplines' (see Rose, 1985), or basically 'mental health services'. For Mad Studies, the indictment of psychiatric oppression includes this wider critique.

Mad Studies defines the relationship between Mad experience and psychiatric oppression as dialectical': 'Mad studies embraces a dialectical perspective ... between the politics of Mad identity and the imperatives of collective struggle against sanism' (Menzies et al, 2013:16, emphasis added). In Mad matters, the concept of'sanism', as a form of oppression specific to Mad people, is defined as: 'the systematic subjugation of people who have received mental health diagnoses or treatment ... sanism may result in various forms of stigma ... discrimination, and ... microaggressions' (LeFrancois et al, 2013: 337).

The argument of Mad Studies in both Mad matters and Psychiatry disrupted is not primarily about the stigma that results from public misperceptions about mental health, which is often the focus of anti-stigma campaigns (Read et al, 2009). Rather, 'mental health diagnoses and treatment' are seen as the direct source of oppression and 
therefore always productive of sanism. This indicates the tightness of the fit between, on the one hand, Mad experience and, on the other, psychiatric oppression. This 'tightness' provides a coherent source of political solidarity - but also begs a number of questions.

First, which part of the madness experience, if anything, pre-dates psychiatric intervention? Could there be Mad people, for example, who are not dialectically connected to the psy disciplines? Is Mad experience completely reducible to sanism? These are questions about those that are external to the 'system', for example, people who are 'Mad' but not subjected to sanism. Second, what about the internal differentiation of madness? Are there any differences within and between those designated Mad? Is every individual on the receiving end of 'diagnoses and treatment' subject to sanism and therefore a subject of Mad Studies? What about those people who experience their involvement with psychiatry as positive (or at least not oppressive) (see Katsakou et al, 2012)?

The three texts differ in the answers provided. Mad matters and Psychiatry disrupted risk a tautological definition of madness. To be identified as Mad is to have experienced sanism; to have experienced sanism involves 'histories of encounters with the psydisciplines' (Menzies et al, 2013: 10). What exists outside of that dialectic may be politically relevant but it could not be Mad. Candidates for relevance may still be political allies: in Diamond's research, they included proponents of anti-psychiatry who had not been 'psychiatrized' - mostly academics and professionals (Diamond, 2013: 66-72) - and 'racialized psychiatrized' women who, while having been the objects of sanism, preferred to identify via categories of gender and race (Diamond, 2013: 69).

So, on the one hand, Mad Studies privileges Mad experience and psychiatric oppression - that is a source of its strength - yet it 'brackets out' the question of what Mad experience might mean external to this. The editors of Madness, distress and the politics of disablement argue that this process of 'bracketing out' risks paradoxically conceding power to psychiatry to define madness - thereby 'letting the dreaded "medical model" in through the back door' (Sapey et al, 2015: 4). This is the problem that Spandler and Anderson (2015: 14) refer to as the 'elephant in the room'. Its presence, though, is addressed in Anne Plumb's (2015) chapter in Madness, distress and the politics of disablement and in Nev Jones and Timothy Kelly's (2015) contribution to the same book. They suggest that it is complexity and heterogeneity - not just sanism - that is constitutive of Mad experience and, therefore, an 'inconvenient complication' to Mad Studies' 'tight' definition of madness. Insofar as Mad Studies 'brackets out' those whose experience of madness has not brought them into contact with psychiatry, or those who have not experienced such contact as oppressive, it introduces tension as well as solidarity into mental health politics.

The second question is about the internal differentiation of madness - judged according to Mad Studies' own definition. Once again, it risks dealing with it tautologically. Given that psychiatric diagnosis itself is a chief culprit of sanism - the Diagnostic and statistical manual of mental disorders (DSM) of the American Psychiatric Association has its own disparaging entry in Mad matters' glossary (LeFrancois et al, 2013: 336-7) - that could not be legitimate criteria for delimiting the scope of madness. What could? Jennifer M. Poole and Jennifer Ward's (2013) discussion of 'grief' in Mad matters seems to provide a clue - for they appear to refer to grief as a non-pathologised state of suffering that is nevertheless counted as Mad. It turns out, however, that Poole and Ward are making a distinction between what they call 
'normal' or 'good' grief and Mad grief. 'Good grief' is time-limited and linear, and welcomes help or intervention from others. 'Mad grief', on the other hand, is defined as a 'resistance practice', which refers to raw experience that opposes or 'breaks the rules' of 'good grief', as defined by the 'grief disorders of the DSMs' (Poole and Ward, 2013: 97). Once again, then, the experience of madness is tied to psychiatric oppression and sanism.

The tension here is that Mad experience sounds like a closed circuit. Internally, madness is identical to resistance to and critique of the psy-disciplines, and it is hard to see what, if anything, lies outside this. What begins as a dialectic of experience 'between ... Mad identity and the ... struggle against sanism' (Menzies et al, 2013: 16, emphasis added) - threatens to fall away into a tautology in which Mad experience just is the struggle against sanism. However, what preserves the dialectical promise of Mad Studies is its commitment to intersectionality and its connection to black feminist thought.

To the theoretical bases of anti-psychiatry, Mad Studies adds the feminism of Patricia Hill Collins (2000) and Dorothy Smith (1990). The consequences of this are productive, for it provides the theoretical tools to escape from the 'closed circuit' noted earlier. It does this in three ways: first, and in line with the critique of Plumb (2015) and Jones and Kelly (2015), noted earlier, through its commitment to the complexity of human experience (as not just Mad, but intersected by gender, sexuality, race, etc); second, through its structural analysis of the psy disciplines as embedded within 'relations of ruling' (which, like neoliberalism, are bigger than psychiatry); and, third, while keeping the dialectic of Mad experience-sanism always in view, through its stress upon the contingency of struggle and suffering. Diamond (2013:74-5) expresses this nuanced account of Mad Studies as follows:

this approach rejects any universal claims made about Mad people.... It recognizes the many different forms of resistance against psychiatric dominance $\ldots$ analyzes their particular social, historical, and material foundations.... It encourages reflection on how diverse perspectives and experiences fit within the larger, comprehensive whole.

\section{Mad experience and Psychopolitics}

Unlike Mad Studies, the experience of madness is not Psychopolitics' raison d'etre; other experiences (of relatives, carers, mental health workers) are equally weighted. Also, although the analysis of Psychopolitics is dialectical, like Mad Studies, it is not, as it is for Menzies et al (2013: 16), a dialectic of Mad experience, but, rather, part of a bigger picture that includes experience alongside politics, economics and ideologies. This 'big picture' approach is characteristic of the Marxist methodology that Psychopolitics inherits from Sedgwick's book of that name, in which any social phenomenon ('mental illness') is conceived as a 'totality' comprising elements that are both 'structural' and 'experiential'. It is these wider sets of relationships, rather than the dyadic relationship between madness and sanism, which interact dialectically for Psychopolitics.

The resurgence of the Psychopolitics tendency post-2008 has followed Sedgwick's 'big picture' approach but dispensed with his preferred terminology ('mental illness' and 'patients') in favour of language that aligns it more closely with Mad Studies, 
for instance, 'distress' in Cresswell and Spandler (2009) and 'alienation' in O'Grady (2014). However, it is not clear whether this constitutes anything more substantial than linguistic modification (Tietze, 2015). The more Psychopolitical contributions to Psychiatry disrupted and Madness, distress and the politics of disablement (McKeown et al, 2014; McKeown and Spandler, 2015) have little to say about the actual experience of madness, and given the neo-Marxist methodology they carry over from Sedgwick, this is not a surprise. The danger in such an analysis is that experience itself becomes one-dimensional or epiphenomenal (see Thompson, 1978); in others words, it risks prioritising social structures over the potential meaningfulness of Mad experience itself. Sedgwick himself did try to maintain a balance between the structural and experiential 'sides' of the dialectic and his activist biography is testament to that (see Davis and Davis, 2015). He was in no doubt, for instance, about the sheer scale of 'mental illness' that contemporary capitalism engendered - but his actual analysis of 'experience', however it is named, never reached beyond the generic category of 'suffering'.

We would say, then, that if Mad Studies engages a 'tight' dialectic in its approach to Mad experience, in which the experience itself threatens to become identical with political practices of resistance and critique, Psychopolitics engages a 'big' dialectic in which generic 'mental illness' remains largely undefined. This, however, does not make it meaningless, for the thrust of the Psychopolitics tendency is that concepts descriptive of human distress, whether they be 'mental illness' or 'madness', are prerequisites for political action. These concepts are what we have called elsewhere a 'political epistemology' (Cresswell and Spandler, 2009). They are usable forms of knowledge (see Cox and Nilsen, 2014) if we want, as Sedgwick (2015 [1982]: 40) implored us, 'to make demands upon the health service facilities of the societies in which we live'. Nevertheless, the tension here is that Psychopolitics could itself be accused of tautology. While, for Mad Studies, madness just is psychiatric oppression, for Psychopolitics, madness just is that undefined state of suffering that demands care and support. This brings us on to the question of service provision.

\section{Service provision}

\section{Service provision and Mad Studies}

Not surprisingly, given the 'tightness' of Mad Studies' identification of Mad experience with psychiatric oppression, it is hostile to the notion of mainstream service provision - services provided to the community to deal with various forms of madness. Mad Studies, as the editors of Mad matters emphasise, 'incorporates all that is critical of psychiatry' (Menzies et al, 2013: 2) and represents the 'struggle against psychiatry in its many forms' (Menzies et al, 2013: 12). Moreover, it equates the broad notion of 'mental health services' with the narrower notion of 'biomedical' or 'biological psychiatry', which it is 'steadfastly arrayed against' (Menzies et al, 2013: 13). At the same time, it is not just 'biological psychiatry', but medicine generally, that it is 'arrayed against' on account of the fact that, as Peter Beresford (2013: ix) remarks in his Foreword to Mad matters, it is '[m] edicalized individual models of mental illness' that have 'been exported to colonize ... and overshadow ... other understandings of [madness]'. It is because of this general hostility to mental health services that Mad 
Studies tends to refer to individuals as 'survivors' rather than 'consumers' or 'service users' (eg Burstow, 2013).

In Psychiatry disrupted, this critique is developed by Burstow as part of a strategy that aspires to nothing less 'than the abolition ... of the psychiatric system' (Burstow, 2014: 37). In Diamond's terms, this 'abolitionist' stance belongs to anti-psychiatry rather than Mad Studies, but this does not preclude the latter mounting a similar indictment of mental health services. This includes critiques of: counselling for the bereaved (Poole and Ward, 2013); psychiatric hospitalisation (Lee, 2013); multidisciplinary community teams (Shimrat, 2013); supported housing projects (Finkler, 2013); and the rerouting of youth in 'racialised inner-city slums' from the criminal justice system to mental health services (Voronka, 2013). The attitude to mental health workers follows the service critique. Small numbers may be allies - mostly of an anti-psychiatry tendency (Diamond, 2013: 66), including radical psychiatrists (Warne, 2013) - but, generally, mental health workers are treated as part of the problem of 'psychiatric hegemony' (Diamond, 2013: 87n) rather than the solution.

Burstow's contribution to Psychiatry disrupted warrants special attention. Probably the most thorough response to the challenge of political strategy yet penned, it details a declaration of principles (Burstow, 2014:39) to be followed to achieve the 'gradual ... rubbing away' (Burstow, 2014: p 38) of psychiatry. Burstow's attitude to service provision follows from these principles, which, in effect, subordinate questions of tactics - Which issues/campaigns should we support now? - to long-term strategy. The question for activists is: '[i]f successful, will the actions or campaigns that we are contemplating move us closer to the long-range goal of psychiatry abolition' (Burstow, 2014: 39). Her answer, as far as service provision goes, is that they must not be supported as they stand, and nor should new ones be countenanced in areas of unmet need. The strategic rationale for this is that 'getting on the bandwagon clamouring for "mental health services" largely means ... services controlled by psychiatry' (Burstow, 2014: 41) and this is incompatible with her 'attrition model for anti-psychiatry'. Whether or not such an anti-psychiatry stance is endorsed by everyone involved in Mad Studies, there are tensions here for it as a political project.

While Mad matters and Psychiatry disrupted both frame Mad Studies as 'open' and inclusive (Menzies et al, 2013; Burstow and LeFrancois, 2014), its stance in terms of service provision remains 'steadfastly' anti-psychiatry and even anti-medical. Psychiatry, the psy disciplines and mental health services are either conflated with, or seen in collusion with, a reductionist account of biological psychiatry. This raises a number of questions. Are all mental health services 'biological' in orientation? What about social psychiatry, 'talking treatments' and social care? Is biology as a science and general medicine as an ethical practice irrelevant to Mad people? This tension is different to that encountered in Mad Studies' approach to Mad experience. There, the 'tightness' of the dialectic between Mad experience and sanism threatened a 'closed circuit' of political identity. In terms of service provision, however, the tension lies in the vagueness of an 'enemy' (psychiatry), which is never precisely defined, but seems to include more or less anything to do with mental health services. The danger here is that the definition of the 'enemy' may include those that could be counted as 'friends' - mainly, mental health workers and/or service users who are not anti-psychiatry and that this could restrict the solidaristic foundation for political action. 


\section{Service provision and Psychopolitics}

By contrast, the defence of mental health services is a core tenet of the Psychopolitics tendency. Whereas, for Mad Studies, biomedical psychiatry and the 'medical model' is the enemy-in-chief, for Psychopolitics, they are not regarded as fundamentally oppressive institutions, but, instead, reformable aspects of welfare.

Mad Studies and Psychopolitics, it seems, possess incompatible conceptions, not just of psychiatry, but of medicine too. This is another aspect of the Sedgwickian legacy. For Sedgwick (2015 [1982]), medicine was not just pharmacology or surgery - or, in psychiatric terms, anti-psychotic medication or electro-convulsive therapy (ECT); it included, in its socialised form, rest, recuperation and therapeutic communities (Spandler, 2014). A classic example of socialised medicine, for Sedgwick, was the 19th-century inclusion of windows into working-class houses. Nor is medicine, as Beresford (2013: ix) maintains, just an individual model, for socialised medicine implies not only the individual 'case', but such sub-disciplines as epidemiology, which is the study of illness en masse. Indeed, one of the main reference works of the contemporary Left is a work of social epidemiology: Richard Wilkinson and Kate Pickett's (2009) The spirit level.

The mandate to defend service provision was explicit in Sedgwick's (2015 [1982]: 40-2) indictment of anti-psychiatry as 'nihilistic' and in his imperative to 'make demands' upon the welfare state. Post-2008 in the UK and the US, that imperative has resulted in campaigns against 'cuts' to mental health services and, in the UK at least, a general media panic about the 'mental health system in crisis' (Boffey, 2016). Cresswell and Spandler (2009), McKeown et al (2014), O’Grady (2014) and Tietze (2015) have reiterated the theoretical underpinnings of these campaigns, while its grassroots manifestations has been recounted by Moth et al (2015) in England, and in America, by the Mental Health Movement, part of the STOP Chicago campaign (Erbentraut, 2012). ${ }^{5}$ Such welfare-related concerns seem of only marginal significance within Mad Studies; in Mad matters, for instance, only Diamond (2013: 72) refers to fears that an anti-psychiatry ideology may fail to respond to the 'lived experiences of psychiatrized people' and their needs for adequate finance, housing and employment.

However, Psychopolitics' defence of mental health services contains its own tensions. Sedgwick was acutely aware of these. A lifelong activist within movements of the British Left, his critique of anti-psychiatry nevertheless included a substantial side-swipe at left-wing approaches to mental health. This had three lines of attack. First, he noted a tendency on the Left to romanticise the experience of madness and construct the Mad individual as a fantasy figure of revolutionary potential. Alongside this fantasy went a minimisation of the actual suffering of the mentally ill and their families. Second, while left-wing campaigns might sound ostensibly about 'defending mental health services', in reality, this often betrayed 'workerist' objectives and goals. In other words, whatever the rhetoric mobilised, such campaigns often buttressed workers' 'terms and conditions' (Sedgwick, 2015 [1982]: 230). Third, while the phrase 'mental health services', in practice, refers to a 'mixed economy' of public, private and voluntary sector service provision, left-wing campaigns usually amounted to a defence mainly of those in the public sector. While staunch in his support for the latter, Sedgwick was a solitary voice on the Marxist Left speaking up for innovative projects located 'outside the bureaucratic compass of the state' (Sedgwick, 2015 [1982]: 252). Nevertheless, despite his critique, Sedgwick remained a revolutionary Marxist 
and while the Psychopolitics tendency aims to 'make demands' upon the current system of welfare, these are defended insofar as they 'prefigure ... the forms that will be characteristic of a society of advanced socialism' (Sedgwick, 2015 [1982]: 277-8).

However, the tensions that Sedgwick identified persist, although they take different contemporary forms. McKeown's (2009) analysis of a mental health nursing strike in Manchester, England, for instance, suggested a continuation of left-wing bias against respected, user-focused, voluntary sector service providers, together with the reinforcement by activists of negative media stereotypes of the 'mentally ill'. In the latter case, this concerned no longer the romanticisation of madness, but, rather, the way in which contemporary discourses of neoliberal governance such as 'dangerousness' and 'risk' (see Szmukler and Rose, 2013) could be deployed in the media to secure public support for the strike while, nevertheless, reproducing myths about madness. While such media interventions might result in short-lived gains, they had the effect of militating against longer-term solidarity and alliance formation with more critical service user groups.

On the other hand, more recent campaigns against 'cuts' in Liverpool, Salford and Norfolk, England, discussed by activist-academics in this journal (Moth et al, 2015), seem to suggest more 'deeply engaged' alliances (see Cresswell and Spandler, 2012; McKeown et al, 2014) between mental health workers and service users, as do the multifaceted campaigns, including occupations, by workers and service users in Chicago, US (see Erbentraut, 2012). Generally, these campaigns remain focused upon the centrality of public sector provision - but they also suggest a more nuanced account of what contemporary alliance formation in mental health might mean for post-Sedgwickian politics.

\section{Critical pedagogy}

\section{Critical pedagogy and Mad Studies}

So far, we have dealt with issues of solidarity and tension primarily in terms of contrasting approaches to Mad experience and service provision. Next, we turn to consider critical pedagogy as a central aspect of both tendencies' activism. By 'critical pedagogy', we are referring to the various forms of knowledge production that underpin the political activism of social movements. Such knowledge may include but does not require teaching programmes within universities. Major contributions to the praxis of critical pedagogy have been made within socialist and feminist traditions (eg Luke and Gore, 1992; Macrine et al, 2010), and Mad Studies provides a new and unique contribution.

The very name 'Mad Studies' entails not only a primary focus upon Mad experience, but also a pedagogical project. This owes a debt to its antecedents in survivor-led research (eg Sweeney et al, 2009) but the explicitly political aspect of the Mad Studies project and its broader pedagogical aims mark it as 'new'. For the Mad matters editors, Mad Studies is a pedagogical approach for 'contesting regimes of truth about "mental illness" and the psy "sciences"' (Menzies et al, 2013: 14) and its potential could be realised both inside and outside of universities. In Mad matters, academia is represented by Kathryn Church (Church, 2013) and David Reville (Reville, 2013), the architects of Mad People's History delivered under the Disability Studies rubric at Ryerson University, Toronto. 
In Madness, distress and the poilitics of disablement, Church (2015) recounts the tensions incumbent upon delivering such an example of critical pedagogy within a university system dominated by neoliberal governance. Despite these frustrations, the inspiration of Reville and Church has been felt within the UK, with Mad Studies courses now being rolled out at Queen Margaret University, Scotland, and Northumbria University, England, ${ }^{6}$ and a regular Mad Studies stream now established in Lancaster University's biannual 'Disability Studies' conference. ${ }^{7}$ Like Church, Beresford and Jasna Russo (2016) are also concerned that the entry of Mad Studies into the university exposes it to the tensions of neoliberal governance; however, they are equally worried that it may succumb to the sort of 'individual competitiveness' and 'abstracted intellectual exercise' (Beresford and Russo, 2016: 2-3) that militates against political solidarity, which we have analysed elsewhere as the general tensions that academics encounter in their engagement with social movements (Cresswell and Spandler, 2012).

As critical pedagogy, Mad Studies aspires to reach beyond, as well as establish itself within, the university. There are precedents for this. In Psychiatry disupted, Ian Parker discusses the formation of the group Psychology/Politics/Resistance (PPR) in the mid-1990s in England. Prefiguring Mad Studies' concern with the psy disciplines rather than solely psychiatry, PPR used the university as a base to organise alliances between academics, clinical psychologists and psychiatric survivors. At that historical juncture, the neoliberal penetration of higher education provided more of an opportunity than the tension it proved later for Beresford, Church, Reville and Russo. As Parker (2014: 56) observes: '[o]ne of the uncomfortable paradoxes of those times was that because higher education institutions were keen to expand their market-share, they were also willing to tolerate the work of young critical academics'.

Echoing the significance of this interface between the university and the psy disciplines as a site of critical pedagogy, in Psychiatry disrupted, Chris Chapman (2014) and Simon Adam (2014) detail the possibilities within teaching and scholarship for exposing, respectively, violence perpetrated by social workers and, from a nursing perspective, the harmful effects of psychiatric medication and ECT. Beresford and Menzies (2014) sum up the challenges facing alliances between the university and Mad Studies and additionally position pro-Mad Studies academics in opposition to pro-biological psychiatry elements of social movement organisations such as the National Alliance on Mental Illness (NAMI) in the US and SANE in the UK, which they argue represent the voices of carers and relatives rather than the 'Mad'. Critical pedagogy's strategic role is envisaged here as radicalising the psy disciplines (in a Mad Studies direction) while providing a bulwark against pro-psychiatry social movements.

\section{Critical pedagogy and Psychopolitics}

Although no autonomous field of inquiry comparable to Mad Studies has emerged within Psychopolitics, critical pedagogy remains central to its activism, especially in the defence of service provision. Nor is it separate from universities within the UK, specifically in the form of the Social Work Action Network (SWAN), ${ }^{8}$ which includes many social work academics of the British Left, and this journal (Critical and Radical Social Work [CRSW]). SWAN hosts an annual conference and has issued an activists' 'mental health charter'. ${ }^{9}$ Indeed, critical pedagogy for the Psychopolitics tendency, in keeping with Sedgwick's legacy, is closely aligned with the contemporary pedagogy of the Left in the UK. 
This leads to distinctive features. First, unlike Mad Studies, Psychopolitics' knowledge production begins not from 'Mad People's History', but, rather, from left-wing political parties and social movement organisations such as the Socialist Workers Party (SWP), SWAN, the public sector trade union UNISON and Disabled People Against Cuts (DPAC). Ideologically, knowledge production springs from the revolutionary Marxist tradition. Second, a key site for pedagogy is not the university, but the actual site in which struggle occurs: mental health services threatened with cuts. In CRSW, Rich Moth, Jo Greener and Trish Stoll (2015) describe recent campaigns against cuts in England involving alliances between service users, mental health workers, trade unions and social movement organisations. Although these are important developments, we would still make the critical point that in the campaigns described, the pedagogical learning taking place at the site of struggle was asymmetrical, involving service users primarily rather than trade unionists or mental health workers: "[a]t a personal level those participating described feelings of empowerment ... [t] he campaigns indicate that service users have been radicalised by the attacks on welfare' (Moth et al, 2015:97).

Our point is not to gratuitously criticise the authors, nor to dispute the democratic structures of these important campaigns, but the tension revealed is nevertheless a significant one within the critical pedagogy of the Left. We would certainly acknowledge it in our own practice. That tension consists in thinking that, as activists, we come only to teach and consciousness-raise and not also to learn and perhaps change our perspectives. In terms of mental health politics, an example of this onedimensional approach to critical pedagogy is the founding historical document of the service user movement in the UK: the famous 'Fish' pamphlet of 1972, otherwise known as 'The Need for a Mental Patients Union'. ${ }^{10}$ Although explicitly Marxist in language - 'an organized Mental Patients Union must take collective action and realize their power in the class struggle' - the pamphlet failed to adequately represent the heterogeneity of ideological perspectives in the grass-roots user/survivor movement, which careful historical research now understands as diverse (see Cresswell, 2011; Spandler, 2006; Survivors History Group, 2011).The risk here is of assuming, or even imposing by means of critical pedagogy, an ideological perspective without adequate engagement with Mad people (see Cresswell and Spandler, 2012). It is with a realistic hope of engagement that we turn to our concluding summary.

\section{Solidarity and tension}

Our purpose in analysing these tendencies has been to balance the tensions and solidarities that exist within and between them. We also wanted to identify particular tensions that we think should not be swept under the carpet. The following summary addresses these aims.

\section{Solidarities and tensions within Mad Studies}

Mad Studies' strength is its political identity as Mad and its identification of Mad experience with psychiatric oppression. This also forms the basis of its expanding programme of critical pedagogy. This is enriched at the theoretical level by drawing on black feminist thought and notions of intersectionality. These could be further integrated in theory and praxis in the years ahead. 
There are two main tensions. The first is a closed circuit of political identity whose reference point is only psychiatric oppression. This is one of the tensions that we do not want to sweep under the carpet. It is not unique to Mad Studies; indeed, in the context of feminism, it has been characterised as a 'wounded attachment' to forms of oppression by Wendy Brown (1995). We follow Brown in seeing this as a tension but also, potentially, as an 'opening' that may be negotiated in the service of democratic politics. However, whether it remains a closed circuit or becomes an opening depends not only on new theoretical resources and new understandings of Mad experience, but also upon the making of productive alliances bringing in new perspectives. This brings us on to the second tension.

Mad Studies' hostility to mental health services restricts the formation of political alliances and, hence, the scope of it as a movement. Of course, this is not a problem if Mad Studies wants to remain small and self-contained - but its expansion in terms of critical pedagogy tends to negate this. Admittedly, the evidence is equivocal. For Burstow $(2013,2014)$, the constituency of Mad Studies sounds coterminous with that of anti-psychiatry and, therefore, small. For Diamond (2013) and Church (2013), however, anti-psychiatry is only one component of a constituency that is potentially wider. Church's (2013) distinction between individuals that are Mad-identified (Mad) and those that are Mad-positive (allies) may help expand Mad Studies as a political and pedagogical project by fostering broader alliances, although this may contain its own tensions.

\section{Solidarities and tensions within Psychopolitics}

Sedgwick's legacy and that of his libertarian Marxism is an ongoing solidaristic foundation - although the time has come to go 'beyond Sedgwick' by incorporating new streams of left-wing and revolutionary thought (eg Cox and Nilsen, 2014). Psychopolitics' refusal to privilege Mad experience paves the way for alliances that mobilise around the defence of the welfare state and potentially includes a much broader constituency.

On the other hand, this strategy potentially alienates Mad activists due to its seemingly uncritical defence of mental health services. In addition, Psychopolitics' failure to define Mad experience leaves it open to charges of relativism - the idea that 'anything goes' in the definition of madness providing that it serves as a rallying cry for fights against 'cuts'. Sedgwick resolved this tension through a redefinition of 'madness' as 'illness' - but post-Sedgwickians are divided on this.

A related tension is the organisational forms that such broad-based alliances require. Although recent theoretical work has focused on this (eg McKeown and Spandler, 2015), it remains an open question as to whether trade unions and the organised Left possess the will for democratic and pedagogical change to enable a 'deeper' and twoway engagement with grass-roots social movements, especially Mad activists. Again, these are tensions that should not be swept under the carpet.

\section{Solidarities and tensions between Mad Studies and Psychopolitics}

However they are analysed, Mad Studies and Psychopolitics are not one unified movement. They are separate tendencies, as outlined in the following: 
- Mad Studies and Psychopolitics each have a different raison d'etre. They are about different 'things'. Mad Studies is about Mad experience and psychiatric oppression; Psychopolitics is about the welfare state and its defence.

- Their attitudes to institutional psychiatry and medicine are diametrically opposed. For Mad Studies, the psy-regime swallows up both psychiatry and medicine and is the source of all harm; it cannot be reformed. For Psychopolitics, whatever their faults, psychiatry and medicine are part of a hard-fought-for welfare state. They may be criticised and reformed but must be defended.

- Both Mad Studies and Psychopolitics see madness and psychiatry as completely intertwined, but in different, potentially opposing ways. Mad Studies sees madness as a critique of and resistance to mental health services; however, Psychopolitics is precisely a demand for such services. These are all tensions that cannot be swept under the carpet.

Having said this, we still see sources of solidarity between Mad Studies and Psychopolitics, as outlined in the following:

- The Mad Studies approach to critical pedagogy should be supported; indeed, one interface of alliance would be its expansion into the pedagogical praxis of trade unions, left-wing parties and social movements. The role of SWAN could be central in building these forms of alliance and the incorporation of Mad Studies' pedagogy could also address some of the democratic tensions traditionally displayed by the Left. In the UK, SWAN's 'charter for mental health' could form a significant rallying point for both tendencies. At the same time, universities within both the UK and North America remain sites in which the critical pedagogies of both tendencies can and do cross-fertilise. ${ }^{11}$

- This requires realistic engagement between Mad Studies' and Psychopolitics' activists. Without seeking some sort of false unification, there are positive signs of this. The fact that the three texts analysed here were published at all, whatever the editorial tensions encountered, is significant. Mad matters itself was certainly warmly received by those in the Psychopolitics tendency (see, eg, McKeown and Spandler, 2013). In the UK, Asylum magazine, ${ }^{12}$ now in its 30th year, continues to provide a forum that welcomes both tendencies; while the survivor-led group Recovery in the Bin shares both a critique of psychiatry as vehement as Mad Studies and an explicit defence of welfare services befitting of Psychopolitics. ${ }^{13}$

- Despite their hostility to mainstream service provision, Mad Studies does envisage voluntary forms of support and compassion, as does Psychopolitics - for the latter, this is an expression of a neglected but still manifest aspect of Sedgwick's prefigurative socialist politics. Examples of voluntary provision cited in Mad matters and Madness, distress and the politics of disablement include: Intentional Peer Support (Minkowitz, 2015: 181); The International Network towards Alternatives and Recovery (Menzies et al, 2013: 9); and Soteria therapeutic communities (Menzies et al, 2013: 5). Such approaches promise new sources of solidarity and, undoubtedly, new sources of tension.

- Finally, while they may be separate tendencies, there is no reason why Mad Studies and Psychopolitics cannot inform and enrich each other. Our point, however, has been that if the underlying tensions are not openly acknowledged and addressed, they may limit the broader alliances - solidarity - that both tendencies seek. 


\section{Notes}

1. See: http://studymore.org.uk/mpu.htm

2. These two tendencies are not the only ones within radical mental health politics.

Other tendencies include resistance to the dominant 'recovery' agenda (see: https:// recoveryinthebin.org/) and human rights-based activism against 'forced psychiatry' (see Minkowitz, 2015).

3. This is by no means a complete analysis. The main omission is any discussion of mental health law and coercion.

4. We define 'dialectic' as two opposing forces (tensions) that strive towards unity (solidarity).

5. See: http://www.stopchicago.org/p/mhm.html

6. See: https://madstudies2014.wordpress.com/mad-studies-courses/

7. See: http://www.lancaster.ac.uk/fass/events/disabilityconference_archive/conference_ home/

8. See: http://www.socialworkfuture.org/

9. See: http://socialworkfuture.org/attachments/article/172/SWAN\%20Mental\%20 Health\%20Charter.pdf

10. See: http://studymore.org.uk/mpu.htm\#FishPamphlet

11. See the conferences 'Mad Positive In the Academy' at Ryerson University, Canada (see: http://ryerson.ca/ds/madpositive/) and 'Unsettling Relations: Mad Studies and the Academy' at the University of Central Lancashire, England (see: http://studymore. org.uk/uclan4b.doc).

12. See: http://www.asylumonline.net/

13. See: https://recoveryinthebin.org/recovery-in-the-bin-19-principles/

\section{References}

Adam, S, 2014, From subservience to resistance: nursing versus psychiatry, in B Burstow, B LeFrancois and S Diamond (eds) Psychiatry disrupted: Theorizing resistance and crafting the (r)evolution, Quebec: McGill-Queens, pp 65-76

Beresford, P, 2013, Foreword, in B LeFrancois, R Menzies and G Reaume (eds) Mad matters: A critical reader in Canadian Mad Studies, Toronto: Canadian Scholars Press, pp ix-xii

Beresford, P, Menzies, R, 2014, Developing partnerships to resist psychiatry within academia, in B Burstow, B LeFrancois and S Diamond (eds) Psychiatry disrupted: Theorizing resistance and crafting the (r)evolution, Quebec: McGill-Queens, pp 77-95

Beresford, P, Russo, J, 2016, Supporting the sustainability of Mad Studies and preventing its co-option, Disability \& Society, 31, 2, 270-4

Boffey, D, 2016, Leaked report reveals scale of crisis in England's mental health services, The Observer, 13 February

Brown, W, 1995, States of injury, Princeton, NJ: Princeton University Press

Burstow, B, 2013, A rose by any other name: naming and the battle against psychiatry, in B LeFrancois, R Menzies and G Reaume (eds) Mad matters: A critical reader in Canadian Mad Studies, Toronto: Canadian Scholars Press, pp 79-90

Burstow, B, 2014, The withering away of psychiatry: an attrition model for antipsychiatry, in B Burstow, B LeFrancois and S Diamond (eds) Psychiatry disrupted: Theorizing resistance and crafting the (r)evolution, Quebec: McGill-Queens, pp 34-51 
Burstow, B, LeFrancois, B, 2014, Impassioned praxis: an introduction to theorizing resistance to psychiatry, in B Burstow, B LeFrancois and S Diamond (eds) Psychiatry disrupted: Theorizing resistance and crafting the (r)evolution, Quebec: McGill-Queens, pp 3-15

Burstow, B, LeFrancois, B, Diamond, S, 2014, Psychiatry disrupted: Theorizing resistance and crafting the (r)evolution, Quebec: McGill-Queens

Butler, J, 1990, Gender trouble: Feminism and the subversion of identity, New York, NY: Routledge

Chapman, C, 2014, Becoming perpetrator: how i came to accept restraining and confining aboriginal children, in B Burstow, B LeFrancois and S Diamond (eds) Psychiatry disrupted: Theorizing resistance and crafting the (r)evolution, Quebec: McGillQueens, pp 16-33

Church, K, 2013, Making madness matter in academic practice, in B LeFrancois, R Menzies and G Reaume (eds) Mad matters: A critical reader in Canadian Mad Studies, Toronto: Canadian Scholars Press, pp 181-90

Church, K, 2015, It's complicated: blending disability and Mad Studies in the corporatising university, in in H Spandler, J Anderson and B Sapey (eds) Madness, distress and the politics of disablement, Bristol: Policy Press, pp 261-70

Cox, L, Nilsen, AG, 2014, We make our own history: Marxism and social movements in the twilight of neoliberalism, London: Pluto

Cresswell, M, 2011, Survivors history and the symbols of a movement, Asylum Magazine, 17, 4, 28-30

Cresswell, M, Spandler, H, 2009, Psychopolitics: Peter Sedgwick's legacy for the politics of mental health, Social Theory \& Health, 7, 2, 129-47

Cresswell, M, Spandler, H, 2012, The engaged academic: academic intellectuals and the psychiatric survivor movement, Social Movement Studies, 12, 2, 138-54

Cresswell, M, Spandler, H, 2015, Psychopolitics today: a response to Tad Tietze, Critical and Radical Social Work, 3, 1, 119-24

Davis, A, Davis, A, 2015, Reading Peter Sedgwick in 2015, http://www.hope.ac.uk/ news/conferences/psychopoliticsc21/resources/

Diamond, S, 2013, What makes us a community: reflections on building solidarity in anti-sanist praxis, in B LeFrancois, R Menzies and G Reaume (eds) Mad matters: A critical reader in Canadian Mad Studies, Toronto: Canadian Scholars Press, pp 64-78

Erbentraut, J, (2012) Chicago mental health advocates put city 'on trial' for consequences of clinic closures, The Huffington Post, http://www.huffingtonpost. com/2012/06/21/chicago-mental-health-clonic-closures_n_1613416.html

Finkler, C, 2013, 'They should not be allowed to do this to the homeless and mentally ill': minimum separation distance bylaws reconsidered, in B LeFrancois, R Menzies and G Reaume (eds) Mad matters: A critical reader in Canadian Mad Studies, Toronto: Canadian Scholars Press, pp 221-38

Hill Collins, P, 2000. Black feminist thought: Knowledge, consciousness and the politics of empowerment, New York, NY: Routledge

Jones, N, Kelly, T, 2015, Inconvenient complications: on the heterogeneities of madness and their relationship to disability, in H Spandler, J Anderson and B Sapey (eds) Madness, distress and the politics of disablement, Bristol: The Policy Press, pp 43-66 
Katsakou, C, Rose, D, Amos, T, Bowers, L, McCabe, R, Oliver, D, Wykes, T, Priebe, S, 2012, Psychiatric patients' views on why their involuntary hospitalisation was right or wrong: a qualitative study, Social Psychiatry and Psychiatric Epidemiology, 47, 7, 1169-79.

Lee, J-E, 2013, Mad as hell: the objectifying experience of symbolic violence, in B LeFrancois, R Menzies and G Reaume (eds) Mad matters: A critical reader in Canadian Mad Studies, Toronto: Canadian Scholars Press, pp 105-21

LeFrancois, B, Menzies, R, Reaume, G, 2013, Mad matters: A critical reader in Canadian Mad Studies, Toronto: Canadian Scholars Press

Luke, C, Gore, J (eds), 1992, Feminisms and critical pedagogy, London and New York, NY: Routledge

Macrine, S, McLaren, PL, Hill, D, 2010, Revolutionizing pedagogy: Education for social justice within and beyond global neo-liberalism, Basingstoke: Palgrave MacMillan

McKeown, M, 2009, Alliances in action: opportunities and threats to solidarity between workers and service users in health and social care disputes, Social Theory \& Health, 7, 2, 148-69

McKeown, M, Spandler, H, 2013, Book review: Mad matters, International Journal of Mental Health Nursing, 22, 5, 472

McKeown, M, Spandler, H, 2015, Solidarity across difference: organising across democratic alliances, in H Spandler, J Anderson and B Sapey (eds) Madness, distress and the politics of disablement, Bristol: The Policy Press, pp 271-86

McKeown, M, Cresswell, M, Spandler, H, 2014, Deeply engaged relationships: alliances between mental health workers and psychiatric survivors in the UK, in B Burstow, B LeFrancois and S Diamond (eds) Psychiatry disrupted: Theorizing resistance and crafting the (r)evolution, Quebec: McGill-Queens, pp 145-62

Menzies, R, LeFrancois, B, Reaume, R, 2013, Introducing Mad Studies, in B LeFrancois, R Menzies and G Reaume (eds) Mad matters: A critical reader in Canadian Mad Studies, Toronto: Canadian Scholars Press, pp 1-22

Minkowitz, T, 2015, Advancing the rights of users and survivors of psychiatry using the UN Convention on the Rights of Persons with Disabilities, in H Spandler, J Anderson and B Sapey (eds) Madness, distress and the politics of disablement, Bristol: The Policy Press, pp 171-82

Moth, R, Greener, J, Stoll, T, 2015, Crisis and resistance in mental health services in England, Critical and Radical Social Work, 3, 1, 89-102

O'Grady, P, 2014, Stop making sense: alienation and mental health, Irish Marxist Review, 3, 11, 36-47

Parker, I, 2014, Psychology politics resistance: theoretical practice in Manchester, in B Burstow, B LeFrancois and S Diamond (eds) Psychiatry disrupted: Theorizing resistance and crafting the (r)evolution, Quebec: McGill-Queens, pp 52-64

Plumb, A, 2015, UN Convention on the Rights of Persons with Disabilities: out of the frying pan into the fire? Mental health service users and survivors aligning with the disability movement, in H Spandler, J Anderson and B Sapey (eds) Madness, distress and the politics of disablement, Bristol: The Policy Press, pp 183-98

Poole, J, Ward, J, 2013, 'Breaking open the bone': storying, sanism and mad grief, in B LeFrancois, R Menzies and G Reaume (eds) Mad matters: A critical reader in Canadian Mad Studies, Toronto: Canadian Scholars Press, pp 94-104

Read, J, Haslam, N, Davies, E, 2009, The need to rely on evidence not ideology in stigma research, Acta Psychiatrica Scandinavica, 119, 5, 412-13 
Reville, D, 2013, Is Mad Studies emerging as a new field of inquiry, in B LeFrancois, R Menzies and G Reaume (eds) Mad matters: A critical reader in Canadian Mad Studies, Toronto: Canadian Scholars Press, pp 170-80.

Rose, N, 1985, The psychological complex: Psychology, politics and society in England, 1869-1939, London, Boston, MA, Melbourne and Henley: Routledge and Kegan Paul

Sapey, B, Spandler, H, Anderson, J, 2015, Introduction, in H Spandler, J Anderson and B Sapey (eds) Madness, distress and the politics of disablement, Bristol: The Policy Press, pp 1-12

Sedgwick, P, 2015 [1982], Psychopolitics, London: Unkant Books

Shimrat, I, 2013, The tragic farce of 'community mental health care', in B LeFrancois, $\mathrm{R}$ Menzies and G Reaume (eds) Mad matters: A critical reader in Canadian Mad Studies, Toronto: Canadian Scholars Press, pp 144-57

Smith, D, 1990, Texts, facts and femininity: Exploring the relations of ruling, London: Routledge

Spandler, H, 2006, Asylum to action: Paddington Day Hospital, therapeutic communities and beyond, London and Philadelphia, PA: Jessica Kingsley Publishers

Spandler, H, 2014, A Sedgwickian philosophy for our times, Philosophy Special Interest Group of the Royal College of Psychiatrists Newsletter, 39, 1-3

Spandler, H, Anderson, J, 2015, Unreasonable adjustments? Applying disability policy to madness and distress, in H Spandler, J. Anderson, B Sapey (eds) Madness, distress and the politics of disablement, Bristol: Policy Press

Survivors History Group (2011) Survivors History Group takes a critical look at historians, in M Barnes and P Cotterell (eds) Critical perspectives on user involvement, Bristol: The Policy Press, pp 7-18

Sweeney, A, Beresford, P, Faulkner, A, Nettle, M, Rose, D (eds), 2009, This is survivor research, Ross-on-Wye: PCCS Books

Szmukler, G, Rose, N, 2013, Risk assessment in mental health care: values and costs, Behavioral Sciences and the Law, 31, 1, 125-40

Thompson, EP, 1978, The poverty of theory, London: New Left Books

Tietze, T, 2015, Peter Sedgwick: mental health as radical politics, Critical and Radical Social Work, 3, 1, 103-7

Voronka, J, 2013, Rerouting the weeds: the move from criminalizing to pathologizing 'troubled youth' in The Review of the Roots of Youth Violence, in B LeFrancois, R Menzies and G Reaume (eds) Mad matters: A critical reader in Canadian Mad Studies, Toronto: Canadian Scholars Press, pp 309-22

Warne, G, 2013, Removing civil rights: how dare we?, in B LeFrancois, R Menzies and G Reaume (eds) Mad matters: A critical reader in Canadian Mad Studies, Toronto: Canadian Scholars Press, pp 210-20

Wilkinson, R, Pickett, K, 2009, The spirit level: Why more equal societies almost always do better, London: Allen Lane 